\title{
KRIMINALITETSUDVIKLINGEN I DANMARK OG OMEGN
}

\section{AF PROFESSOR, DR. JUR. FLEMMING BALVIG}

The most interesting thing concerning crime trends in Denmark during the last two to three decades is their similarity to trends found in most other industrialised countries. This similarity presents a challenge to the two classical ways of thinking about how to reduce crime: the penal control model and the social welfare model. The penal control model assumes that a large police force and harsh punishments can reduce crime, while the social welfare model is grounded in the assumption that social welfare and equality in earnings can do the same. The effectiveness of both models is challenged by the fact that crime trends appear uniform regardless of which model a particular country embraces. A closer analysis shows that the two models are negatively correlated opposites in practise and confirm that neither of them is strongly related to crime levels.

The analysis also show that while the social welfare model seems to be positively related to the feelings of security, the penal control model is correlated with increased fear. These facts are discussed within the context of current political trends in Denmark, where the social welfare model is rapidly loosing ground to the penal control model - as it is in most other industrialised countries. This change is unlikely to affect crime rates, but may well stimulate increased fear of crime and reinforce the social polarisation and social exclusion processes already in motion.

Der er fire forhold, som er særligt karakteristisk for den danske befolknings forhold til de former for adfærd, man har valgt at gøre strafbare. Det første er kriminalitetens almindelighed, det andet kriminalitetens ualmindelighed, det tredje Danmarks ualmindelige almindelighed og det fjerde Danmarks almindelige ualmindelighed. Det lyder som om disse forhold strider mod hinanden. Hvilket de da også gør - på én måde. På én anden måde gør de det ikke: Det er fire billeder - fire perspektiver - der hver for sig siger noget vigtigt om kriminalitetens niveau og udvikling i Danmark. Ingen af billederne er i sig selv helt rigtige, men i kombination opfanger de væsentlige sider af den modsætningsfyldte virkelighed, der præger kriminalitetsfænomenet i et samfund som det danske.

\footnotetext{
* Title in English: Crime Trends in Denmark and the Industrialised World. Original in Danish.
} 


\section{Kriminalitetens almindelighed i Danmark}

Der foretages hvert år i Danmark millioner af strafbelagte handlinger, så mange at det i virkeligheden er ganske absurd at spørge, om der var flere sidste år end forrige år, og om der er flere eller færre end i f.eks. Sverige. Lovovertrædelserne $i$ et moderne samfund som det danske er især knyttet til de centrale positioner, som menneskers og varers mobilitet og cirkulation har. Alene af de politiregistrerede lovovertrædelser er det mindst tre ud af fire handlinger, der enten retter sig mod et eller andet transportmiddel og/eller som begås ved hjælp af et sådant. Kunne vi opgøre den samlede mængde lovovertrædelser, ville disse handlinger givet vise sig at være fuldstændig dominerende.

Selve tyverierne og anden form for traditionel straffelovskriminalitet kan vi sætte visse tal på. Den første repræsentative tyveriofferundersøgelse blev foretaget i 1972. Den viste, at godt 13 procent havde været udsat for tyveri inden for det seneste år. En tilsvarende undersøgelse foretaget 30 år efter, i 2002, viste knapt 17 procent, så måske er der sket en vis stigning. I så fald ligger stigningen primært $\mathrm{i}$ 1970erne, og ikke i det seneste kvarte århundrede. I undersøgelsen fra $1972 \mathrm{blev}$ der også spurgt om hærværk. 7 pct. havde været udsat det seneste år - nøjagtig den samme andel af befolkningen som 30 år senere, i 2002, gav udtryk for, at de havde været udsat for hærværk. Sammenlignelige offerundersøgelser for vold findes i Danmark først fra 1987, hvor en undersøgelse viste, at 2,7 pct. havde været udsat for vold. I den hidtil seneste undersøgelse, fra 2002, er den tilsvarende procent 2,3. Fra og med 1987 er det også muligt at sige noget om, hvor stor en del af befolkningen, der i løbet af et år har oplevet sig udsat for tyveri, vold og/eller hærværk (se tabel 1 næste side). I 1987 var det 25 pct., i 200224 pct. - altså en fuldstændig stagnation, som underbygges af unders $ø$ gelser foretaget $\mathrm{i}$ de mellemliggende år: 1991: 26 pct., 1996: 25 pct., 1998: 23 pct., 2002: 26 pct. og 2001: 24 pct.

Mens hverdagskriminaliteten eller trivialkriminaliteten således har været stagnerende, så er det noget, der tyder på, at der dels er blevet flere, og at det dels er blevet mere socialt udbredt at drage økonomisk fordel af andres kriminalitet i form af direkte hæleri. I samme boldgade er der en veldokumenteret stærk og markant stigning i det almene tyveri fra fællesskabet i form sort arbejde. Marxistiske analyser er ikke længere så populære, som de var engang, men med øje for det centrale er det inden for denne analyseramme blevet fremhævet, at tyverierne funktion i et moderne samfund er at bidrage til recirkulation af fastfrossen kapital. Dette er efter min vurdering mere vigtigt og rigtigt end nogensinde. Hvad man kunne kalde for det udvidede hæleri er nærmest eksploderet i omfang og er blevet et dagligdags grundtræk i et moderne samfund som det danske. Hæleri i snæver forstand vedrører aftagelse af tyvekoster. Hæleri i udvidet forstand vedrører alle andre former for $\emptyset$ konomiske transaktioner, der beror på - eller som begrundes i - at der begås tyveri eller anden form for kriminalitet. 
Tabel 1. Kriminalitetens omfang og udvikling i Danmark, 1987-2002 (udvalgte typer af lovovertradelser)

\begin{tabular}{|c|c|c|c|c|c|}
\hline & \multicolumn{4}{|c|}{$\begin{array}{l}\text { Procent af befolkning der seneste år har } \\
\text { været udsat for: }\end{array}$} & \multirow[t]{2}{*}{$\begin{array}{l}\text { Anmeldte straffelovsover- } \\
\text { trædelser (afrundet) }\end{array}$} \\
\hline & Vold & Hærværk & Tyveri & $\begin{array}{l}\text { Vold, hærværk } \\
\text { og/eller tyveri }\end{array}$ & \\
\hline 1987 & 3 & 12 & 15 & 25 & 524.000 \\
\hline 1988 & & & & & 537.000 \\
\hline 1989 & & & & & 537.000 \\
\hline 1990 & & & & & 527.000 \\
\hline 1991 & 3 & 11 & 14 & 26 & 520.000 \\
\hline 1992 & & & & & 537.000 \\
\hline 1993 & & & & & 547.000 \\
\hline 1994 & & & & & 547.000 \\
\hline 1995 & & & & & 539.000 \\
\hline 1996 & 2 & 10 & 16 & 25 & 528.000 \\
\hline 1997 & & & & & 531.000 \\
\hline 1998 & 2 & 8 & 14 & 23 & 499.000 \\
\hline 1999 & & & & & 494.000 \\
\hline 2000 & 3 & 7 & 17 & 26 & 504.000 \\
\hline 2001 & 3 & 9 & 15 & 24 & 473.000 \\
\hline 2002 & 2 & 7 & 17 & 24 & 491.000 \\
\hline 2003 & & & & & 486.000 \\
\hline
\end{tabular}

Med hensyn til det udvidede hæleri er det anderledes svært at sætte tal på, men der er ikke skygge af tvivl om, at der her er sket en eksplosion. Det antal mennesker, der tjener på andres kriminalitet og kriminalitetsfænomenet som sådan og det antal kroner, der tjenes, er vokset voldsomt. Sporene heraf er stærkt synlige og mærkbare for den enkelte dansker i dagligdagen. Man kan ikke lukke sig ud af sin dør, lukke sig ind i en bil, handle i en forretning, hæve penge, zappe igennem tv-kanalerne på sit tv-apparat eller høre sin politiker udtale sig om de vigtigste samfundsproblemer uden at komme i berøring med kriminaliteten. Kriminaliteten er alle vegne i det moderne danske samfund. Fanomenet kriminalitet er og har været i voldsomt stigning. 


\section{Kriminalitetens ualmindelighed i Danmark}

Til trods herfor må det være på tide at afsløre en af de bedst bevarede hemmeligheder, der skjuler sig bag disse - selvfølgeligt i sig selv alt for høje - kriminalitetstal: Denne hemmelighed er, at det kriminalpræventive arbejde i Danmark er en bemærkelsesværdig succes. Det er lykkedes at holde kriminaliteten nede i en sådan grad, at næsten alle næsten hele tiden overholder straffeloven. Det være sig unge som gamle, kvinder som mænd, nydanskere såvel som ikke helt så nye danskere. Det er især bemærkelsesværdigt, fordi vi alle fødes og starter som barbarer, og fordi der kan være vældig mange gode grunde til at overtræde loven: Opdagelsesrisikoen er i al almindelighed minimal; straffen er i de fleste tilfælde kun en bøde; der kan være store gevinster at hente ved tyveri; vold kan give respekt osv.

Også i historisk og geografisk perspektiv er det kriminalpræventive arbejde i Danmark en succes. Historisk set er det mest bemærkelsesværdige den fredeliggørelse, der er sket af danskernes dagligdag. I 1800-tallet var daglige tæsk og bank en realistisk trussel for en stor del af befolkningen. Skolelærerne bankede eleverne, mestrene bankede lærlingene, forældrene bankede børnene, manden bankede hustruen, børnene bankede hinanden. Som det hele har udviklet sig, er vi nu nået frem til den situation, at mellem 97 og 98 procent af befolkningen i Danmark i løbet af et år ikke udsættes for nogen form for vold fra nogen som helst. Det er en kulturrevolution, dagligdagen i Danmark har gennemgået, når det drejer sig om risikoen for fysisk personvold.

Der er i vort nuværende samfund givetvis langt flere tyverier og mere hærværk end førhen, men dette betyder ikke nødvendigvis, hverken at moralen er faldet på dette felt, eller at tyverierne er blevet en større belastning. Formentlig forholder det sig stik modsat. Det er jo ikke så underligt, at der ikke stjæles cykler, hvis cykler ikke findes, og det er nemmere at komme sig over et tyveri af en cykel i dag, end det var at komme sig over et tyveri af en trækvogn i 1850 . Formentlig modstår vi langt flere fristelser til at stjæle end nogensinde end før, og vor rigdom, forsikringsdækning og sociale system betyder, at vi almindeligvis ikke rammes nær så hårdt og indgribende, som i fattigdomssamfundet. Tidligere kunne tyveri af f.eks. mad eller t $\varnothing \mathrm{j}$ være livstruende for en stor del af befolkningen.

I år 2000 blev Danmark for første gang placeret på det kriminalistiske verdenskort gennem sin deltagelse i de internationale offerundersøgelser (ICVS). Ser vi på ofrene for de mest alvorlige personforbrydelser, viser det sig, at en lang række lande i den industrialiserede del af verden med sikkerhed kan siges at være belemret med mere alvorlig kriminalitet end Danmark: Det drejer sig f.eks. om lande som Canada, USA, Polen, Sverige, Australien, England \& Wales, New Zealand og Italien. Der er derimod ikke et eneste af de mange undersøgte industrilande, der med statistisk sikkerhed kan siges at placere sig med et lavere niveau for alvorlig kriminalitet end Danmark - omend Finland er lige ved. 
De seneste par år har seksuelle overfald været særligt i fokus. Også på dette specifikke område viser de internationale offerundersøgelser, at Danmark hører til blandt de mindst kriminelt belastede lande.

Det er endvidere ikke blot den "objektive" tryghed, der er exceptionel høj i det moderne danske samfund; den subjektive er det i endnu højere grad. Der er intet andet samfund af de undersøgte, hvor så mange er trygge ved at færdes ude om aftenen efter mørkets frembrud - og hvor så mange er trygge ved at være alene hjemme - som i Danmark.

Man kan sige, at alverden burde strømme til Danmark for at studere dette vellykkede kriminalpræventive "eksperiment". Set som en helhed er det svært at se, at der er ret mange andre lande, et land som Danmark kan lære af - men let at se, hvor utroligt mange lande, der kunne lære noget af Danmark.

I en vis udstrækning har omverdenen da også opdaget dette lille fredelige land. Undersøgelser af, hvad det især er, turister sætter pris på ved det danske samfund, viser således, at det i meget høj grad netop drejer sig om, at Danmark efter deres mening og oplevelse er et meget trygt land at besøge.

Hvis det nu er rigtigt, at Danmark hører til blandt de i kriminalpræventiv henseende mest succesfulde lande i verden, hvad bør så være konsekvenserne heraf?

Konsekvensen bør naturligvis ikke være, at man slår sig til tåls med situationen. Man skal gøre, hvad der er muligt og hensigtsmæssigt for at bringe kriminaliteten endnu længere ned, og man skal hjælpe ofrene betydeligt mere og bedre, end man allerede $g \varnothing r$.

Der er imidlertid to yderligere konsekvenser, som er mindre indlysende. Den første er, at man bør være sig bevidst, at yderligere nedbringelse af den alvorligere kriminalitet er forbundet med helt særlige vanskeligheder i nutidens Danmark sammenlignet med tidligere tider og sammenlignet med en række andre lande. Det har været langt lettere at komme frem til den gunstige situation, vi befinder os i nu, end det vil vise sig at være at presse kriminalitetsbarometeret yderligere $\mathrm{i}$ bund.

Den anden konsekvens er, at man selvfølgelig bør være stolte og glade over situationen; man bør ikke være bange for at rose og lykønske hinanden og det samfund, vi befinder os i. Den i forhold til kriminaliteten særligt store tryghed i Danmark bør selvfølgelig "på plakaten", såvel nationalt som internationalt. En erkendelse af og en bevidstg $\varnothing$ relse omkring, at det kriminalpræventive arbejde i Danmark arbejder i rygvind, tror jeg faktisk, er en af de vigtigste forudsætninger for at opnå endnu bedre resultater.

Fremhævelsen af og fokuseringen på den kriminalitet, der ikke forekommer - hvor medieuegnet den end er - er vigtig for tryghedsfølelsen, for tryghedsfølelsen er mere afhængig af forestillinger end realiteter. Det kan derfor betyde, at flere tør færdes på gaden, og flere mennesker på gaden betyder mindre gadekriminalitet, mindre risiko for bande-territorialitet mv. 
Specielt for unge er fokuseringen på andre unges dominerende lovlydighed uhyre vigtig, fordi billeder af "ungdom=kriminalitet" kan opbygge flertalsmisforståelser, som på sin side kan virke som selvopfyldende profetier: Den kriminalitet, der ikke var der til at begynde med, bliver en realitet, fordi man gerne vil stå sig godt i forhold til de andre unge, som man tror lægger vægt på, at man begår forskellige former for kriminalitet. Hen over sommeren 2000 domineredes mediebilledet af en fremstilling af ungdommen i Danmark som en ungdom på extacy, selv om de foreliggende undersøgelser viste, at unge, der blev tilbudt stoffet, næsten altid sagde nej, og at under 5 procent havde prøvet det. Virkeligheden var altså, at danske unge sagde nej til extacy - men risikoen foreligger for, at det forvrængede offentlige billede gennem sine konsekvenser efterfølgende kan have retfærdiggjort sig selv.

Det er ikke blot i den mediemæssige og politiske offentlighed, at det er forbløffende, hvor ensidigt fokus er på kriminalitet, og hvor ringe interessen er for den dominerende lovlydighed i et samfund som det danske; det er også forbløffende, at det samme gør sig gældende i forskningen. Heller ikke i kriminologien er der således en grundlæggende erkendelse af, at det er lovlydighed og ikke kriminalitet, der gør Danmark specielt og unikt. Næsten alle studier handler om de kriminelle. Fokus er på højkriminalitetsområderne frem for lavkriminalitetsområderne, på de mest kriminelle aldersgrupper, det mest kriminelle køn, de mest kriminelle etniske grupperinger osv.

Konsekvensen heraf er, at vi ved en del om, hvad der skaber kriminalitet, men meget lidt om det mest almindelige og udbredte, dvs. hvad der skaber lovlydighed. Det er som om, man blot tager lovlydighed for givet, og ikke forestiller sig, at der kan være forskelle eller ske ændringer heri, der kan være interessante. Det er min påstand, at man herved kan komme til at overse centrale forhold, som kan få afgørende betydning for, om vi kan fastholde den relativt store tryghed i fremtiden, f.eks. vedrørende ungdomskriminalitetens udvikling.

I forbindelse med spørgeskemaundersøgelser af selvrapporteret kriminalitet blandt unge i henholdsvis 1979 og 1999 blev der gennemført en del personlige interviews om følgende tema: Begrundelser for $i k k e$ at begå kriminalitet. F.eks. blev de unge spurgt om, hvorfor de ikke havde begået cykeltyveri, eller - hvis de nu rent faktisk havde stjålet cykler - hvorfor de ikke havde gjort det flere gange end tilfældet var.

Det er karakteristisk, at de unge i 1979 næsten alle syntes, at dette var et ejendommeligt og mærkeligt spørgsmål. Det var der også mange, der mente i 1999, men her var der alligevel flere, der ikke syntes, det var så ejendommeligt endda, og som umiddelbart svarede på spørgsmålet. Det var tydeligt, at de havde tænkt over det ved en tidligere lejlighed. 
Tillige er der fa 1979 til 1999 sket markante ændringer i forekomsten af forskellige typer af begrundelser:

En del begrundelser er blevet mindre almindelige. Det er f.eks. begrundelser som:

Det $g \varnothing r$ man bare ikke.

Det ville være forkert.

Det har jeg aldrig tænkt på.

Det ville være synd for den, det gik udover.

Det ville være ondt.

Dvs. begrundelser, der fokuserer på, at man undlader at begå kriminalitet af hensyn til det fælles: "Det ville være dumt - for andre!"

Men der er også begrundelser der er blevet mere almindelige. Det er begrundelser som:

Det ville ødelægge det for mig.

Jeg ville ikke turde.

Jeg kunne blive opdaget; det er for svært.

Det ville komme på min straffeattest.

Der er andre måder at nå det samme på.

Dvs. begrundelser, der fokuserer på, at man undlader at begå kriminalitet af hensyn til én selv: "Det ville være dumt - for mig!"

Den dominerende lovlydighed synes at hvile på et helt andet grundlag i dag end for nogle årtier siden. Den har ændret sig fra at bygge på "det ukrænkelige" til at bygge på "det individuelt fornuftige"; fra et styrende "man" til et styrende "mig". Udviklingen kan skildres i positive termer: mindre autoritetstro, større selvstændighed, større uafhængighed, større voksenhed - eller i negative: større egoisme, større selvcentrering, mindre interesse for ofre, større kynisme osv. - og der er jo såvel positive som negative sider af udviklingen. Umiddelbart har udviklingen betydet mindre ungdomskriminalitet, men det er vist ikke svært at forestille sig, at det ændrede grundlag for lovlydighed fremover kan presse kriminalitets-kurverne opad igen?

Den mere grundlæggende pointe er, at hvis man ikke i et land som Danmark kommer til besindelse og vover at se danskernes omfattende og exceptionelle lovlydighed i øjnene - og det grundlag hvorpå denne lovlydighed hviler - samt indretter vore forventninger og handlinger på det kriminalpolitiske område i overensstemmelse hermed, så kan man ende op som et knuget og frygtsomt folkefærd bekæmpende en monster-struktur af bander og galninge, der på en vis måde så er en realitet - men som er blevet det helt eller delvist på grund af vore militante forsvarsmanøvrer mod og ekskluderinger af alt og alle, der kan virke fremmed og truende, og som passer ind i vort billede af ikke-lovlydighed som den fremherskende tilstand. 


\section{Danmarks ualmindelige almindelighed}

Den indbyggede påstand i det forudgående afsnit er, at kriminalitetsbilledet i Danmark er ualmindeligt. Denne påstand skal ikke få lov at stå alene længe, for påstanden i indeværende afsnit er, at kriminalitetsbilledet i Danmark er såre almindeligt.

De internationale offerundersøgelser viser således, at det omkring årtusindeskiftet ikke blot er Danmark, der er karakteriseret ved, at omkring hver fjerde indbygger oplever sig udsat for tyveri, hærværk og/eller vold i løbet af et år. Rigtig mange moderne industrialiserede samfund ligger omkring dette niveau. Der er selvfølgelig nogen, der ligger højere, og nogen, der ligger lavere - men ingen der ligger rigtig meget højere og ingen der ligger rigtig meget lavere. Der er f.eks. ingen af de moderne industrisamfund, hvor mere end halvdelen udsættes for kriminalitet - og heller ingen hvor mindre end hver tiende udsættes.

Hvad mere er, så peger tendenserne over tid i Danmark i samme retning som andre steder. De fleste industrialiserede samfund har oplevet en stigning i kriminaliteten under udviklingen af de moderne bysamfund og den sociale kategori, der kaldes ungdom. Kriminalitetskurverne pegede gennemgående opad i 1950erne og/eller 1960erne og/eller 1970erne. Det var først og fremmest disse stigninger, der blev dokumenteret, analyseret og diskuteret, da kriminalitetsudviklingen i de nordiske lande blev debatteret på det nordiske kriminalistmøde for 20 år siden, i 1984. Med opbremsningen i den moderne byvækst, institutionaliseringen af ungdoms-kategorien, faldende og stagnerende ungdomsårgange og fremvæksten af den situationelle kontrol med befolkningen som en vigtig samfundsfaktor - herunder den situationelle kriminalprævention - har tendenserne ændret sig. Med forskellig styrke og med forskelligt starttidspunkt synes de stærke stigninger at være afløst af mindre stærke stigninger, stagnation eller direkte fald i trivial- og hverdagskriminaliteten set under ét. For Danmarks vedkommende kan man efter smag og behag vælge at tale om stagnation eller fald $\mathrm{i}$ kriminaliteten. Offerundersøgelserne, hvis hovedresultater er nævnt ovenfor, tyder nærmest på stagnation, mens tendensen for de politianmeldte straffelovsovertrædelser den seneste halve snes år snarest har været et fald (se tabel 1).

Den bemærkelsesværdige internationale ensartethed, som synes at have udviklet sig, og som karakteriserer såvel kriminalitetens trend som niveau, genfindes for Danmarks vedkommende også som en intranational tendens. Af offerundersøgelserne fremgår, at forskellene mellem forskellige geografiske områder, f.eks. opdelt efter befolkningstæthed, er blevet mindre, og at nivelleringen er sket ved, at kriminaliteten har været stagnerende eller faldende i de største byområder (i særdeleshed hovedstadsområdet), mens den har været stigende i de mindste byområder. På basis af bevægelser i tallene for de politianmeldte straffelovsovertrædelser har man talt om, at "kriminaliteten flytter mod vest" - og at det måske direkte kunne skyldes, at de kriminelle flyttede - men der er nok snarere tale om forhold, der er betinget af ændringer i de enkelte områders egne forudsætninger. 
Den internationale ensartethed er en udfordring til de i politisk henseende to store dominerende modeller for, hvordan kriminalitet forebygges og formindskes. Den ene er den strafferetlige kontrolmodel, hvor kriminaliteten søges bekæmpet gennem trussel om og/eller iværksættelse af negative sanktioner. Den anden er den sociale velfærdsmodel, hvor kriminaliteten søges bekæmpet gennem (re)etablering af gode socio- $\varnothing$ konomiske livsomstændigheder. Industrilandene imellem findes der en betydelig variation i såvel omfanget af den strafferetlige kontrol som i velfærdsniveau, og umiddelbart synes denne variation således ikke at give sig udslag på kriminalitetsbarometrene. Det kan der være mange grunde til, som ikke bunder i fejl i selve teorierne, f.eks. usammenlignelige kriminalitetsbarometre, skjulte/betingede/falske sammenhænge osv. Der er dog vel næppe nogen, der tvivler på, at kriminaliteten i hvert fald ikke kun påvirkes af den strafferetlige kontrol og/eller den sociale velfærd. En af de interessante muligheder er, at det kan skyldes, at sammenhængene eksisterer, men at der skal meget betydelige forskelle i strafferetligt kontrolniveau og/eller velfærdsniveau til for at afstedkomme selv små forskelle eller ændringer i kriminalitetsniveauet. Denne mulighed ville stemme godt overens med megen anden kriminologisk forskning på området.

For at afprøve om de kriminalitetsforskelle, der faktisk eksisterer mellem Danmark og en række andre lande, kan relateres til forskelle i strafferetligt kontrol- og/eller velfærdsniveau, er der gennemført en mindre analyse. Analysen omfatter i alt 9 EU-lande, der er udvalgt ud fra følgende kriterier:

- De har deltaget i de internationale offerundersøgelser gennemført i 2000 og kan således på visse områder sammenlignes kriminalitetsmæssigt.

- Der foreligger også sammenlignelige indikatorer for de "uafhængige" variable, dvs. det strafferetlige kontrol- og velfærdsniveau.

- Der er betydelig forskel på landenes placering på de centrale (uafhængige) variable, mens der er betydelig lighed på andre områder, herunder de kulturelle, således at disse forhold i en vis udstrækning kan "holdes konstant" $i$ analyserne.

- Der er for de centrale variable større forskelle mellem landene (internationalt) end inden for de enkelte lande (intra-nationalt).

- Det er muligt at vurdere gyldigheden af de målestokke, der anvendes, for såvel de afhængige som de uafhængige variable.

De 9 lande, der indgår i analysen, er følgende: Danmark, Sverige, Finland, Holland, Belgien, Storbrittanien, Frankrig, Spanien og Portugal. Et element i det udvidede hæleri de seneste årtier er, at kriminalpolitik ikke længere kun drejer sig om den objektive tryghed, dvs. fravær af strafbare handlinger, men også den subjektive, dvs. fravær af frygt eller angst for kriminalitet. Den afhængige variabel tryghed er derfor i analyserne opdelt i objektiv og subjektiv tryghed.

I figur 1 er skitseret den common-sense kriminalpolitiske model, der er undersøgt. Her er det formodningen, at den strafferetlige kontrolmodel og velfærdsmo- 
dellen alternerer, dvs. at jo mere et samfund baserer sig på den ene, desto mindre baserer det sig på den anden. Endvidere er det formodningen, at øget objektiv tryghed betyder $\emptyset$ get subjektiv tryghed. For det tredje formodes det, at den strafferetlige kontrolmodel og velfærdsmodellen virker på samme - positive - måde, dvs. at begge er i stand til at øge trygheden, såvel den subjektive som den objektive.

Den strafferetlige kontrolmodels volumen i de enkelte lande er målt ved antal indsatte pr. 100.000 indbyggere og valideret mod politistyrkens størrelse. Den sociale velfærdsmodels volumen er målt ved sociale bidrag pr. indbygger og valideret mod henholdsvis de sociale ydelsers andel af bruttonationalproduktet og gini-indeks der måler uligheder i indkomst. Den objektive tryghed er målt ved risikoen for i løbet af et år at blive udsat for vold, tyveri, hærværk eller seksuelle overgreb, der betragtes som meget alvorlige af dem, det er gået udover (ICVS). Denne målestok er valideret ved at beregne korrelationen mellem de enkelte kriminalitetsformer samt korrelationen mellem risikoen for forskellige aldersgrupper, køn, uddannelsesgrupper og geografiske områder. Endelig er den subjektive tryghed målt ved et indeks for, hvor tryg man føler sig henholdsvis uden for og i sit hjem (ICVS), og valideringen er her foretaget ved at beregne korrelationer mellem tryghed inden for og uden for hjemmet samt graden af tryghed for forskellige aldersgrupper, $k ø n$, uddannelsesgrupper og geografiske områder.

Valideringsforsøgene tyder på, at mens målestokkene for kontrolpolitik, velfærdspolitik og subjektiv tryghed er valide, så er de det ikke for objektiv tryghed. Kriminalitetsrisikoen er ikke en endimensional størrelse.

Figur 1. En teori om betydningen af kontrol- og velfærdspolitik for befolkningens tryghed

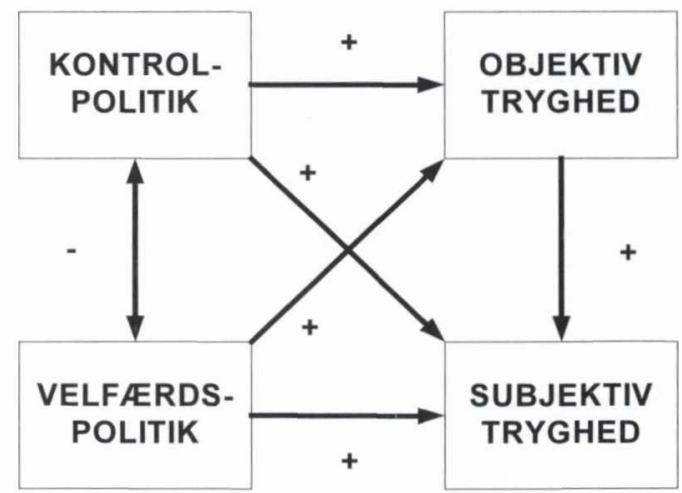

Selve analysen er foretaget i form af rangkorrelationer (Spearman's rangkorrelationskoefficient). Figur 2 viser, hvilke sammenhænge, der har overlevet de statistiske signifikanstests. Den grundlæggende formodning om, at internationalt er den strafferetlige kontrolmodel og velfærdsmodellen alternerende, 
bekræftes. Jo mindre social velfærd og jo større indkomstuligheder mv., desto større politistyrke og brug af fængsler.

Derimod bekræftes den anden grundlæggende formodning om, at subjektiv tryghed følger i kølvandet på objektiv tryghed ikke. Dette er kriminologisk set ikke særligt overraskende, for mange andre analyser har vist, at kriminaliteten og angsten herfor på mange måder lever hver deres selvstændige liv og påvirkes af meget forskellige faktorer, jf. også tidligere.

Figur 2. Sammenhænge mellem kontrol- og velfærdspolitik på den ene side og befolkningens tryghed på den anden (baseret på en analyse af 9 EU-lande)

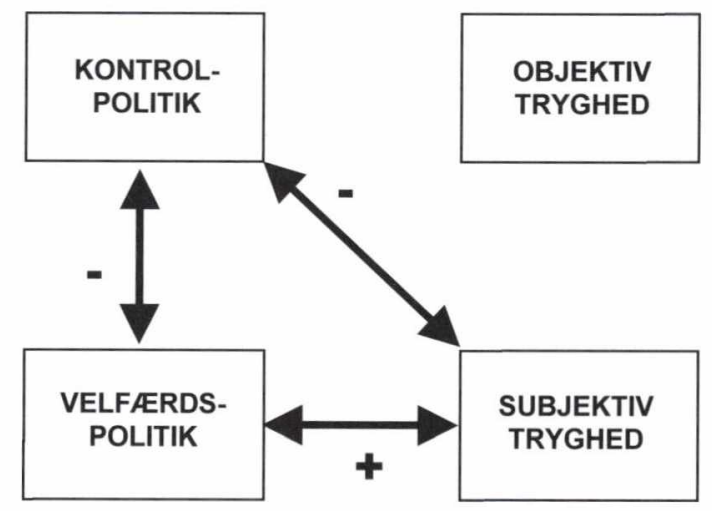

Talrige analyser har vist, at store forskelle i brugen af strafferetlige kontrolmidler ikke kan forklares ved forskelle i kriminalitetsniveauer. Når der således i analysen ingen korrelation findes overhovedet mellem den strafferetlige kontrol og den objektive tryghed, tyder det på, at der altså heller ikke er nogen effekt den modsatte vej. De forskelle, der findes mellem de 9 landes polistyrker og anvendelse af fængselsstraffe, synes ikke at påvirke borgernes risiko for at blive udsat for relativ alvorlig kriminalitet. Der er heller ikke noget, der tyder på, at relativt store politistyrker og mange i fængsel får borgerne til at føle sig mere trygge. Tværtimod er der her en statistisk signifikant korrelation, der peger i stik modsat retning. Kun en analyse over tid - og den må afvente, at de internationale offerundersøgelser forhåbentlig snart gennemføres på ny - kan afdække denne relations nærmere beskaffenhed. I figur 2 er det foreslået, at den går begge veje: Jo mere utryg en befolkning føler sig, desto større basis for mere politi og mere brug af straf - og jo mere politi og straf, desto større fokus på og dramatisering af kriminalitetsproblemet i et samfund og derfor også desto mere frygt og angst for kriminalitet.

Velfærdsmodellen derimod synes netop på dette område at give, hvad der er et af dens formål at give, en større følelse af tryghed. Jo større mulighed for at 
blive kompenseret i tilfælde af nød og jo større indkomstlighed, desto mindre bange føler befolkningerne sig. En nærmere analyse på et mere omfattende materiale tyder på, at effekten især skyldes, at sociale ordninger medfører en mindre sårbarhedsfølelse, altså en følelse af bedre at kunne klare og komme sig over overgreb mv., hvis uheldet skulle være ude. Der er således også en sammenhæng mellem forsikringsordningers omfang og betydning ved kriminalitet $\mathrm{i}$ de enkelte lande på den ene side og fraværet af angst for kriminalitet på den anden. I den forbindelse er det et interessant spørgsmål, hvilken betydning de særlige ordninger og arrangementer for ofre for kriminalitet, såsom f.eks. offerrådgivninger og krisecentre kan tænkes at have. I de mere detaljerede analyser er også dette forsøgt evalueret. I disse analyser indgår i alt 12 lande, og der er anvendt en metode, hvor det faktiske subjektive tryghedsniveau er sammenholdt med det statistisk forventelige ud fra de empiriske relationer mellem disse variable. Af analyserne fremgår det, at i to lande - især Nordirland, men også Holland - er den faktiske subjektive tryghed i befolkningen større end man skulle forvente ud fra eksistensen af de materielle økonomiske forsikrings- og kompensationsordninger mv. Nordirland placerer sig som en suveræn nr. 1 blandt de 12 analyserede lande efter, hvor mange der har fået specialhjælp af krisecentre mv. 21 pct. af alle ofre (der har politianmeldt indbrud, røveri, seksuelle krænkelser eller trusler/vold) har fået en sådan form for støtte i Nordirland. I Danmark er denne procent 8. Også Holland placerer sig i den øverste ende på ranglisten over, hvor stor en andel af ofrene, der har fået speciel støtte, og Holland er helt i top (nr. 1) efter, hvor få blandt de ikke hjulpne, der gerne ville have haft hjælp. Omvendt kan man se, at Polen og Frankrig er de to lande, hvor den faktiske tryghed afviger mest i negativ retning i forhold til det forventede, og her viser det sig, at billedet er det stik modsatte af situationen i Nordirland og Holland med hensyn til støtte fra krisecentre mv. Begge disse to lande ligger i den absolut nedre ende, når det drejer sig om, hvor mange ofre, der har fået hjælp.

Det ser altså ud til selvstændigt at bidrage væsentligt til den almene befolknings tryghedsfølelse i dagligdagen, at der eksisterer tilbud om hjælp af mere bred social og psykologisk karakter til ofre for indbrud, røverier, seksuelle krænkelser, trusler og vold.

Som for den strafferetlige kontrolmodel findes der til gengæld ingen sammenhæng mellem det volumen, de sociale velfærdsordninger har i de enkelte samfund, og omfanget af traditionel straffelovskriminalitet. Totalt set synes dette at bekræfte, hvad der som tidligere omtalt også allerede indiceres af kriminalitetsudviklingen i Danmark og andre industrialiserede lande efter anden verdenskrig, nemlig at der på makroniveau er andre kraftigere trækkende lokomotiver for kriminalitetsudviklingen end strafferetlig kontrol og sociale velfærdordnin- 
ger. Man bør dog her erindre sig, at vi netop fandt, at den anvendte målestok for objektiv tryghed ikke var endimensional. Der kan således tænkes at komme andre og mere nuancerede konklusioner frem ved analyser af mere specifikke kriminalitetsmålestokke, f.eks. af ældres og unges kriminalitetsrisiko hver for sig. Der er kun svage sammenhænge mellem ældres og unges kriminalitetsrisiko blandt de analyserede lande. Forskellige aldersgruppers kriminalitetsrisiko synes altså at være påvirket af helt eller delvist forskellige forhold. Omfanget af den strafferetlige kontrol viser sig urelateret til såvel ældres som unges kriminalitetsrisiko. Velfærdsvolumet derimod er positivt relateret til ældres objektive tryghed, dvs. jo større velfærdsniveau, desto mindre kriminalitetsrisiko for ældre. Velfærdsvolumet er ikke relateret til unges kriminalitetsrisiko. Her synes især alkoholforbruget at være en faktor af langt større betydning.

Det er blevet hævdet, at den nordiske velfærdsmodel er en myte. Ikke desto mindre forholder det sig sådan, at i EU - og formentlig globalt - ligger de nordiske lande helt $\mathrm{i}$ top, når det drejer sig om mål for sociale tilskud til de enkelte borgere, de sociale ydelsers andel af bruttonationalproduktet og lighed i indkomster. Det er også en realitet, at de nordiske lande ligger helt i top i EU - og formentlig globalt - når det drejer sig om den subjektive tryghedsfølelse. Analyserne tyder på, at det ikke er tilfældigt, at de nordiske lande ligger i top på begge målestokke. Den relativt lave grad af angst og frygt for kriminalitet i Danmark og i de andre nordiske lande synes i betydelig grad at være et produkt af de udviklede velfærdsordninger. En anden side af den nordiske velfærdsmodel er det relativt lave niveau af strafferetlig kontrol i form af forholdsvis små politistyrker og forholdsvis små fangebefolkninger. Dette synes både at være muliggjort af og selvstændigt at have bidraget til det relativt høje subjektive tryghedsniveau.

Derimod er det nok i overvejende grad en myte, hvis man forestiller sig, at den nordiske velfærdsmodel skulle kunne skabe et paradis på jord fri for kriminalitet lige så meget som det er en myte, at dette skulle være muligt via ekspansiv brug af strafferetlig kontrol i form af store politistyrker og mange fængselsceller.

\section{Danmarks almindelige ualmindelighed}

Pointen i det forudgående afsnit har været kriminalitetsudviklingens og kriminalitetsniveauets bemærkelsesværdige lighed med andre industrialiserede lande og de små forskelles gabende kedsommelige forudsigelighed. Alt synes at nivellere sig, inden for som mellem samfund. Man kunne imidlertid lige så godt hævde, at det modsatte gør sig gældende, og dette skal være afskedsreplikken i denne artikel.

Der findes to typer meget ualmindelige mennesker i Danmark: Dem der stort set aldrig begår kriminalitet - og dem der begår meget kriminalitet. Pointen er, at disse ualmindelige grupper synes at blive stadigt mere almindelige. Med andre ord, at der foregår en polarisering. 
Parallelt med det almene fald i ungdomskriminaliteten, dvs. i de mere lejligheds- og situationsprægede berigelsesforbrydelser og i volden, der er konstateret i Danmark, er der også sket en polarisering af kriminalitetens fordeling blandt unge og forankring i ungdommens situation. Der er ingen tvivl om, at ungdomskriminaliteten som i 1960erne og 1970erne stadig helt grundlæggende har karakter af "kriminalitet som normalitet" eller "nuancer i gråt" i såvel den forstand, at de fleste af og til begår kriminalitet, som at det også gælder for unge med gode skoleforhold o.lign., men denne karakteristik er ikke længere helt så dækkende, som den var dengang.

De relativt lidt kriminelle unge er blevet endnu mindre kriminelle end før, og de relativt meget kriminelle unge er blevet endnu mere kriminelle. De grå nuancer i kriminalitetsbilledet er blevet færre og de sorte og hvide flere og tydeligere. Der er blevet færre, der kriminalitetsmæssigt kan danne bro mellem de konforme og de ikke-konforme, færre som de helt lovlydige kan sige kun er lidt mindre lovlydige end de selv er, og færre som de meget kriminelle kan sige er lidt mindre kriminelle end de selv er. Det er i højere grad blevet "vinderne" over for "taberne".

Indbygget i den rent statistiske polariseringstendens synes således også at være en $\emptyset$ get marginalisering af de kriminelle og en $\emptyset$ get ekskludering af de to grupper - de "ikke-kriminelle" og de "kriminelle" - i forhold til hinanden.

Den i kriminalpræventiv henseende positive side af denne proces er, at den sandsynligvis har virket forstærkende på faldet $\mathrm{i}$ den almene ungdomskriminalitet, fordi den har gjort ikke-kriminel adfærd (endnu mere) acceptabel og gangbar blandt de i forvejen lidet kriminelle. Det gælder såvel med hensyn til kriminalitet som tyveri og vold som med hensyn til rygning af tobak og hash. I forlængelse af en form for fremtids-disciplinering, der har fundet sted, er det ikke blot i stigende grad blandt disse "vindere" blevet anset som dumt for dem personligt at begå risikable former for tyverier, vold mv., men det har også - ved det stærkere sammenfald med skoleproblemer mv. - i stigende grad fået et image som adfærd, der begås af nogen, der er meget anderledes end én selv: de dumme.

Den kriminalpræventive - og medmenneskelig set - negative side af processen er, at den samtidig i stigende grad har fastlåst de mest kriminelle i deres situation og overladt dem til hinanden. I og med at det er blevet dem, "de andre ikke vil lege med", dvs. have som venner og kammerater, er sandsynligheden også mindsket for, at de kan ændre på deres egen situation. Denne større fastlåshed betyder formentlig, at det er mere følelsesmæssigt og socialt belastende at være i denne situation end tidligere, og det er muligvis i dette perspektiv de gennemgående meget stærke stigninger i brugen af rus- og nydelsesmidler blandt de kriminelle unge i Danmark skal ses.

Det skal være påstanden her - og det kan kun blive en påstand, for der er ikke plads til forsøg på dokumentation - at polariseringen dels ikke kun markerer sig i ungdomskriminalitetsbilledet som sådan, men også på en række andre må- 
der i det danske samfund, og dels at det ikke kun gør sig gældende i Danmark. På dette område er det ellers ualmindelige blevet mere almindeligt i Danmark, og den danske situation som sådan er - i et internationalt perspektiv - almindelig.

I et fremtidsperspektiv er det mest bekymrende, at der de seneste årtier sideløbende med de faktiske polariseringsprocesser gradvist er sket en ændring i det kriminalpolitiske paradigme, der i sine konsekvenser sandsynligvis vil betyde en endnu kraftigere polarisering. Mens velfærdsparadigmet har inkludering som hovedformål, har det strafferetlige kontrolparadigme ekskludering som konsekvens. Og det er jo denne transformation vi i Danmark, som i de fleste andre lande er vidne til: En mindre vægtning af de velfærdspolitiske midler og en større af de strafferetlige. Flere har betegnet det som overgangen fra det moderne til det senmoderne i samfundsudviklingen. Overordnet kan man sige, at kriminalpolitik i det moderne samfund søges styret af bedst mulig viden (professionelle eksperter) med henblik på det fælles bedste. Kriminalpolitik i det moderne samfund er et rationel/bureaukratisk velfærdsprojekt. Prototypen - for Danmarks vedkommende - for denne form for kriminalpolitik er den lovgivning mv., der førte til en væsentlig reduktion $\mathrm{i}$ anvendelsen af tidsubestemt frihedsstraf - og frihedsstraf som sådan - i 1973. I det senmoderne samfund styres kriminalpolitik af det politiske system med henblik på at repræsentere befolkningens følelser bedst muligt og at give det enkelte individ beskyttelse og tryghed - og dermed frihed her og nu. Kriminalpolitik i det senmoderne samfund er et emotionelt/demokratisk beskyttelsesprojekt. Prototypen - igen for Danmarks vedkommende - for denne form for kriminalpolitik er den lovgivning mv., der f.eks. betød iværksættelse af en ny ungdomssanktion i Danmark og ny lovgivning mv. vedrørende terrorisme. Internationalt er "Three Strikes"-lovgivningen det bedst kendte eksempel på en kriminalpolitik, der udformes som et emotionelt beskyttelsesprojekt snarere end som et raionelt velfærdsprojekt.

Den tidligere omtalte tendens til udvidet hæleri knytter sig til udviklingen af dette nye "senmoderne" kriminalpolitiske paradigme, såvel som en vigtig forudsætning som en konsekvens heraf. De væsentligste forklaringer på paradigmeskiftet er - som jeg ser det - velfærdsstatens krise i det moderne samfund, "fremmetheden" der aktualiserer det eksistentielle spørgsmål om, hvem man kan stole på samt individualiseringen som bl.a. indebærer tabet af de to traditionelle tryghedsgestalter - familien og religionen. Det traditionelle samfunds store bekyttere Gud og Mor er væk. Det moderne samfunds Penge og Partnere kunne ikke erstatte dem. Nu søges den eksistentielle tryghed i det individualiserede "fremmede" senmoderne samfund hos Læger og Politi.

Det er som fremgået yderst tvivlsomt, om man der vil finde det man søger. Det er derimod ikke særlig tvivlsomt, at det vil gøre det ualmindelige mere almindeligt, dvs. at polariseringen vil øges, og at ekskluderinger af dem vi med eller uden grund er bange for vil tiltage i omfang og styrke. Hvor kirken tjente som det traditionelle 
samfunds pyramider og socialcentrene som det moderne samfunds, ser det ud til, at det nu i den sen- eller eftermoderne periode bliver fængslerne, der indtager en sådan position - i Danmark - og i Danmarks omegn, for ikke meget på det kriminalitets- og kriminalpolitiske område ser ud til at være mere almindeligt end det vi har set ske og udvikle sig i Danmark siden kriminalistforeningerne seneste havde disse spørgsmål på programmet i det Orwell’ske år, 1984, for tyve år siden.

\section{Vigtigste litteratur:}

Balvig, F.: "Kriminalitetsudviklingen i Danmark 1950-82", Nordisk Tidsskrift for Kriminalvidenskab, maj 1984, s. 83-108.

Balvig, F.: RisikoUngdom. Ungdomsundersøgelse 1999. Det Kriminalpreventive Råd, København, 2000.

Balvig, F.: "Danmark du dejligst", Lov \& Ret, juni, 2001, s. 10-15.

Balvig, F.: "Kriminaliteten i Danmark - i europæisk perspektiv", Juristen, nr. 7, september 2001, s. 263-283.

Balvig, F.: "Straf og tryghed", Lov\&Ret, december 2003, s. 3-8.

Falck, S. m.fl.: Nordic Criminal Statistics 1950-2000. Stockholms Universitet, 2003.

van Kesteren, J. m.fl.: Criminal Victimisation in Seventeen Industrialised Countries. Key findings frem the 2000 International Crime Victims Survey. NSCR, 2000.

Kriminalstatistik, udgivet af Danmarks Statistik, diverse år.

Mayhew, P. m.fl.: Criminal Victimisation in Eleven Industrialised Countries. Key Findings from the 1996 International Crime Victims Survey. NCRS, 1997.

von Hofer, H.: "Brott och straff i Skandinavien. En överblick", Nordisk Tidsskrift for kriminalvidenskab, 2003, s. 178-191.

Adresse:

Det Juridisk Fakultet

Forskningsafdeling III

Sankt Peders Stræde 19

DK-1453 København K.

flemming.balvig@jur.ku.dk 